Ilmu Pertanian (Agricultural Science)

Vol. 2 No. 2 August, 2017 : 048-055

Available online at http://journal.ugm.ac.id/jip

DOI: doi.org/10.22146/ipas.16983

\title{
Population of Herbivorous and Carnivorous Arthropods in Rice Field Ecosystem Modified with Vermicompost and Flower Plants
}

\author{
Suparni*, Nugroho Susetya Putra, Suputa \\ Departement of Plant Protection, Faculty of Agriculture, Universitas Gadjah Mada \\ Jl. Flora 1 Bulaksumur, Sleman, 55281 Yogyakarta, Indonesia \\ *Corresponding email: suparnie_77@yahoo.co.id
}

Received: $6^{\text {th }}$ December 2016 ; Revised: $4^{\text {th }}$ January 2017 ; Accepted: $29^{\text {th }}$ August 2017

\begin{abstract}
Biological diversity index could be used as an option to assess the stability of an agricultural ecosystem. This limited field research was aimed to determine the effect of vermicompost and flowering plants (Asteraceae) to the diversity of herbivore and carnivore arthropods $(\mathrm{M}+)$. Conventional treatment with the application of non-organic fertiliser and without the addition of flowering plant was used as control (M0). Sampling was conducted using insect nets, and began at 30 days after planting (DAT), and repeated every other week until before harvesting. The results showed that the diversity of herbivore and carnivore arthropods in modified plots with organic fertiliser worm cast and flower plants/habitat manipulated system $(\mathrm{M}+$ ) was moderate (herbivores: Shannon diversity index from 1.1 - 2.2; carnivores: 1.93 - 2.09), as well as the diversity of arthropods in the field of non-modified/custom system (M0) (herbivores: Shanon index of 1.2 - 1.7; carnivore: 1.34 - 2.18). Meanwhile, the number of arthropod species found in the M+ plot was 59 species, consisted of 22 herbivores and 37 carnivores ( 9 order, 32 families, and 35 genera). Number of arthropods found in the M0 plot was 54 species, consisted of 17 species of herbivores and 37 species of carnivores ( 7 orders, 28 families, and 30 generas). Statistical analysis showed that there was no significant difference in the plot diversity M+ and M0. Nevertheless, mean diversity of the $\mathrm{M}+$ plot tended to be higher (Shannon Index herbivore and carnivore $=1.6=2.01$ ) compared with M0 plot (herbivore and carnivore $=1.45=1.76$ ).
\end{abstract}

Keywords: Glyphosate, Paraquat, Tobacco Plant, Weed

\section{INTRODUCTION}

Rice ecosystem is unstable, which is indicated by low biological diversity. It might due to the intensive use of synthetic pesticides and fertilisers. For example, the use of synthetic pesticides in excessive amounts causes imbalance abundance of herbivores and natural enemies (Herlinda et al., 2008). In addition, the use of synthetic fertilisers in excessive amounts can cause a decline in soil fertility, water and soil pollution, as well as a decrease in crop productivity (Chandra, 2005). Thus, synthetic pesticides and fertilisers potentially decrease the stability and resilience of the whole ecosystem (Pimentel and Edwards, 1982), as well as incurring high recovery cost in human health problems, degrading environmental quality, and increasing the incidences of pest resistance (Pimentel et al., 1992). Therefore, the balance of agricultural ecosystem management needs to be done. Aryantha (2002) describes two things that need to be carried out in order to create a balance agroecosystem, i.e. (1) improving soil fertility using organic matter and beneficial microbes, and (2) controlling the population of plant pests by empowering natural enemies.

Two strategies can be carried out as follows. First, using more organic than synthetic fertilisers. Research showed that organic fertilisers allowed several advantages, such as maintain $\mathrm{C} / \mathrm{N}$ ratio in soil, improve the physical, biological and chemical soil, improve soil structure and texture, increase water holding capacity of soil, increase the biological activity of the soil, provide available nutrients for plants, as well as reduce the level of soil evaporation through increased soil moisture (Chandra, 2005; Supartha, et al., 2012). In addition, organic fertilisers can also stimulate the growth of plant roots and increase soil microbial activity (Marpaung, 2014). Another study conducted by Hadi et al. (2015) reported that the diversity and abundance of 
soil arthropod populations in an organic farm ecosystems tended to be higher than in inorganic rice fields. Meanwhile, Settle et al. (1996) reported that the amendment of organic matter in technically irrigated rice field was able to increase the detritivore populations and water plankton which was very useful to feed insects, especially generalist predators at the beginning of the growing season before the main prey population was sufficient.

The second strategy is to empower natural enemies by planting refugia plants to enhance the population, and therefore to strengthen their role to control pests. Refugia plant is an area or a shelter which allows natural enemies to hide and survive in the agricultural ecosystem (Wilkin et al., 2016), and can be planted on the border or in the farm (Muhibah and Leksono, 2015). The effect of plants on the diversity and abundance of insect herbivore and carnivore has been widely reported. Research on the interaction between the ladybird (Curinus coeruleus Mulsant) and flowering plants Hibiscus brackenridgei by Krakos et al. (2011) showed that this plant served as source of nectar or as an alternative food for ladybird. Weeds and plants which produce pollen can also be used as food source, shelter and breeds for natural enemies (Laba et al., 2000). Silveira et al. (2009) stated that Marigold (Tagetes erecta L.) grown next to the main crop onions could increase the diversity of arthropods, especially the natural enemies. The abundance of hemipteran carnivore was also reported to increase in areas with flowering plants (Frank and Kunzle, 2006).

This study was done to investigate the interaction impact of vermicompost as organic fertiliser and flowering plants as conservation sites for natural enemies on the abundance and diversity of herbivore and carnivore arthropods in a limited field study.

\section{MATERIALS AND METHODS}

Research was conducted in November 2015 April 2016, in rice field at Mancasan village, Baki subdistrict, Sukoharjo district, Central Java Province. The rice field was an irrigated system, which was previously being conventionally managed, and then changed into semi-organic management two years before the research was started. Two treatments were applied, i.e.: (1) custom treatment (conventional system) (code: M0), and (2) habitat manipulated system (code: $\mathrm{M}+$ ) which were described below. The 21-day-old of Situ Bagendit rice variety were planted in $28 \mathrm{~cm} \times 28 \mathrm{~cm}$ row spacing, with two seedlings per hole. The distance between observation plots was three meters.

\section{Custom System (M0)}

In this treatment, plots were treated the way it usually handled by local farmers, and used as control plots. This treatment used urea as nitrogen fertiliser (300 $\mathrm{kg} \mathrm{ha}^{-1}$ or equal to 750 gram per plot), SP-36 as phosphat fertiliser $\left(100 \mathrm{~kg} \mathrm{ha}^{-1}\right.$ or equal to 250 gram), and $\mathrm{KCl}$ as kalium fertiliser $\left(100 \mathrm{~kg} \mathrm{ha}^{-1}\right.$ or equal to 250 gram), respectively (Widiarta et al., 2006). Fertilisation was performed three times: at 7-10 day after planting (DAT) SP36 was applied in the field, then at 21 DAT, and 35-40 DAT half of urea and $\mathrm{KCl}$ was respectively applied.

\section{Habitat manipulated system (HMS/M+)}

This plot was treated with a 8 ton $\mathrm{ha}^{-1}$ or equal to $20 \mathrm{~kg}$ per plot of worm cast at three days before planting (Kariada \& Aribawa, 2005). Single row of flower plants in polybags were arranged in every four to six rows of paddy

\section{Arthropod sampling}

Observation and sampling of arthropods were performed firstly at 30 days after planting, then repeated every other week until a time before harvesting by using insect nets (sweep net). Three samples were collected from each plot. Then, the collected arthropods were put into a large plastic bag with chlorophorm, and stored in small bottles that had been filled with ethanol $70 \%$. Identification carried out at Laboratory of Basic Entomology, Faculty of Agriculture, Universitas Gadjah Mada. Arthropod collections were grouped into three categories, i.e. herbivores (pests), carnivore (predators and parasitoids), and detritivore

\section{Measurement of Diversity Index}

Diversity index of herbivore and carnivore arthropods was analysed using Shannon-Wiener diversity index (Krebs \& Kenney, 2011) as formulated below:

$$
\mathrm{H}=-\sum_{t=1}^{s} P_{i} \ln P_{i}
$$

whereas: $\mathrm{H}=$ number of species in all sampling plots; $\mathrm{S}=$ species richness or total amount of the species; $\mathrm{Pi}=$ proportion of total species $\mathrm{i}$ in sample plot or proportion of total specimen of species and number of specimen of all species.

With the provision of an index value : $\mathrm{H}<1=$ Low diversity; $1<\mathrm{H}<3=$ Moderate diversity; $\mathrm{H}>$ $3=$ High diversity.

\section{Statistical Analysis}

Data were analysed using t-test analysis at the 
significance level of $5 \%$, using SAS (Statistical Analysis System) versi 9.3 64-bit portable software. (Hanafiah, 2010).

\section{RESULT AND DISCUSSION}

\section{The Population Abundance of Herbivore and Carnivore}

Observation on the abundance of herbivore and carnivore populations in the research field showed the following research findings. Figure 1 showed that the population of the herbivores in the manipulated plot $(\mathrm{M}+)$ peaked in the third observation (58 DAT). Meanwhile, the population of the herbivores in the non-manipulated plot (M0) peaked in the fourth observation (72 DAT). It meant that the peak population reached by herbivores in non-manipulated plot tended to be slower than in the manipulated plot

The observation also indicated that the population of carnivores tended to follow the changes in the population of herbivores (Figure 2). The population of the carnivores in both plots showed similar tendency, reaching a peak in the fifth observation.

Table 1 showed the pattern of the abundance of herbivores in two different plots. In the manipulated plot, Stenchaetothrips sp., Cofana sp., and N. lugens were more abundant than the other three species. On the other hand, in non-manipulated plots, $N$. lugens and $L$. oratorius were more abundant than the other four species. Table 1 also showed that Stenchaetothrips sp. and Cofana sp. in the manipulated plot were higher than those in the non-manipulated plot, but $N$. lugens and $L$. oratorius in the non-manipulated plot were more abundant than those in the manipulated plot.

Table 2 showed the number of carnivorous arthropods in the manipulated plot was higher than those in the non-manipulated plot, even though their abundance in the last plot was bigger than those in the manipulated one. There were two different kinds of carnivores found in the manipulated plot, i.e. Dolicophodid Syntormon sp. and Linyphiid Atypena $\mathrm{sp}$. However, they were not found in the non-manipulated plot.

Meanwhile, Figure 3 showed the average population of the herbivores in the manipulated plot was higher than in the non-manipulated one, although it was not significantly different. On the other hand, the population of the carnivores in the non-manipulated plot was higher than in the manipulated one.

\section{The Diversity of Herbivorous and Carnivorous Arthropods}

The result showed that the diversity of the herbivorous and carnivorous arthropods in both plots were not significantly different (Table 3 ). Table 1 indicated that the diversity of herbivores in both plots was similar. On the other hand, the diversity of the carnivores in the manipulated plot was higher than that in the non-manipulated one.

Table 3 showed that the diversity of the herbivorous and carnivorous arthropods in both plots was not significantly different, although there was a tendency that the index of arthropod diversity in the manipulated plot $(\mathrm{M}+)$ was higher than in the non-manipulated one (M0).

\section{The Abundance of Other Arthropods}

The result showed that the average of the population and the diversity index of other arthropods, including decomposers (Collembola and the like) and pollinators

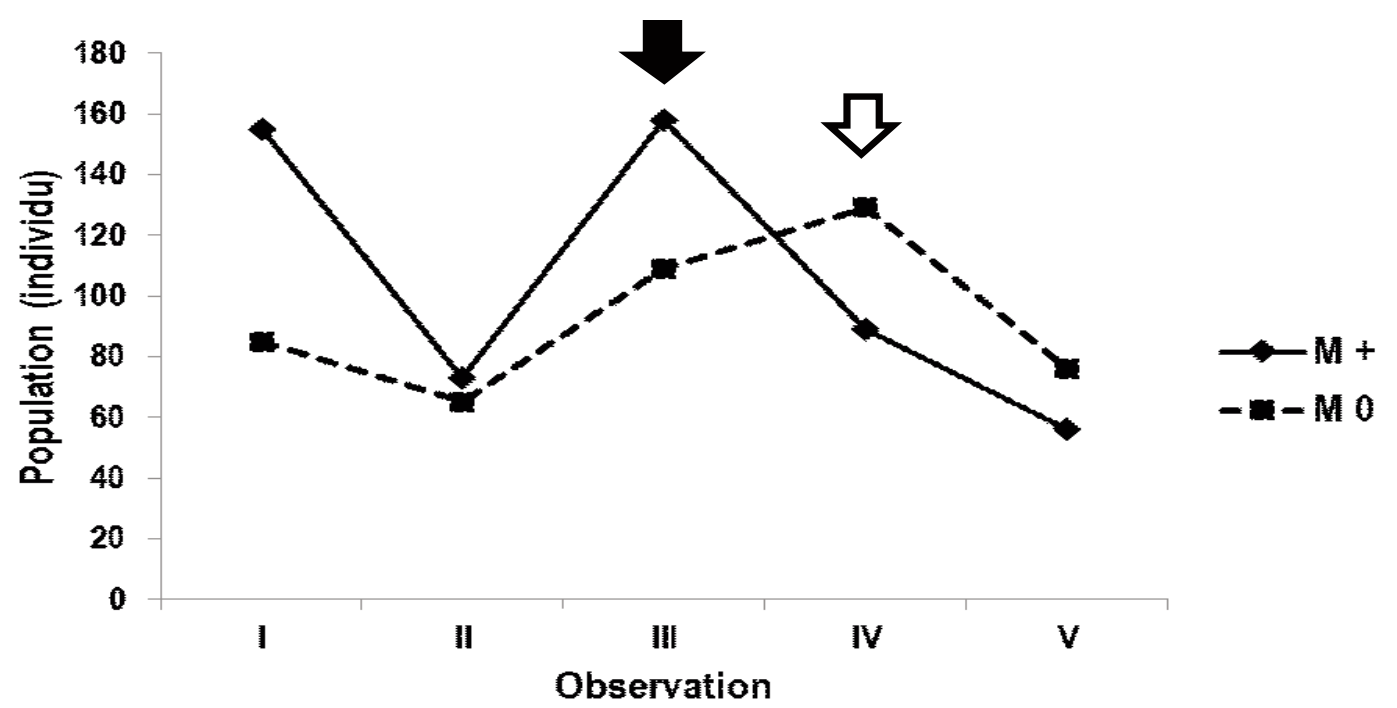

Figure 1. Fluctuation of the herbivores in the manipulated (M+) and the non-manipulated (M0) plots. The black arrow indicates the peak of the population of herbivores in the manipulated plot while the white arrow indicates the peak of the population of the herbivores in the non-manipulated plot. 


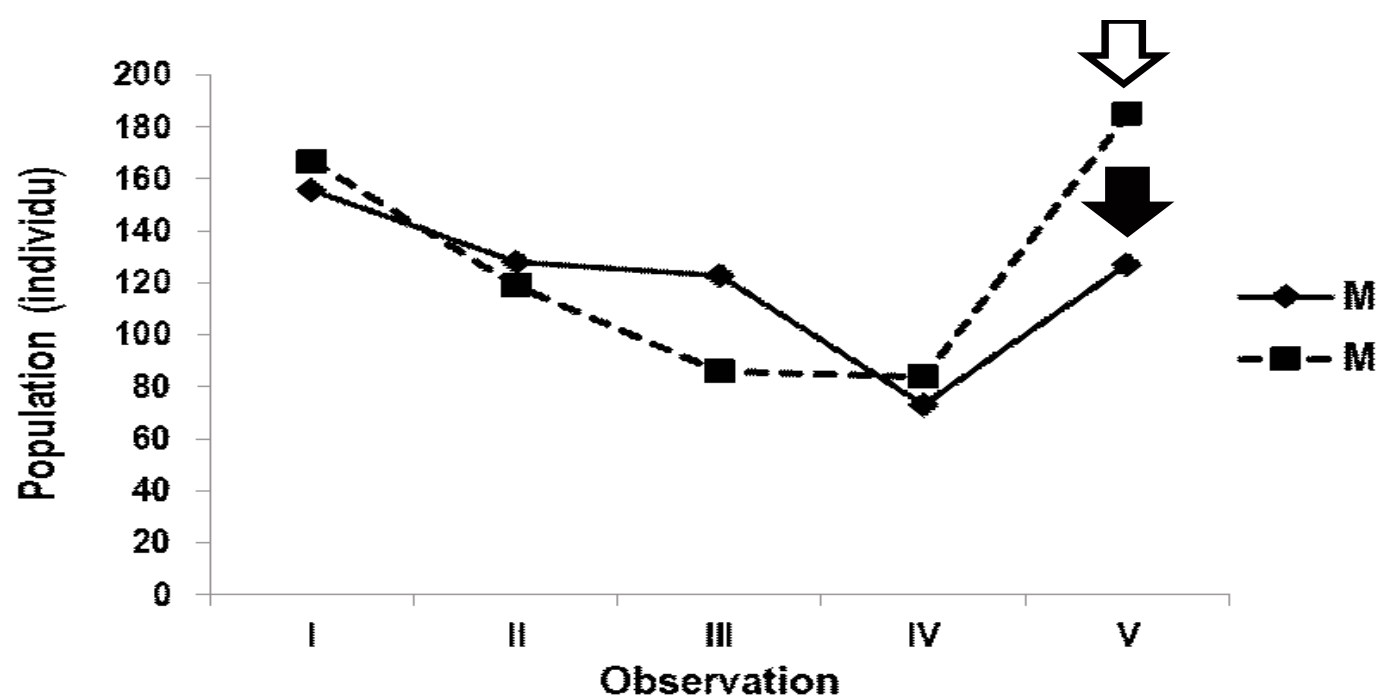

Figure 2. Fluctuation of the carnivores in the manipulated $(\mathrm{M}+)$ and the non-manipulated $(\mathrm{M} 0)$ plots. The arrows indicated the peak of carnivore population in the manipulated (black arrow) and non-manipulated (white arrow) plots.

Table 1. The abundance of herbivores found in manipulated plots (M+) and non manipulated plots (M0)

\begin{tabular}{clllcc}
\hline \multirow{2}{*}{ No } & \multirow{2}{*}{ Order } & \multirow{2}{*}{ Family } & \multirow{2}{*}{ Genus/species } & \multicolumn{2}{c}{ Abundance } \\
\cline { 4 - 5 } & & & Manipulated plot (M+) Non Manipulated Plot (M0) \\
\hline 1 & Thysanoptera & Thripidae & Stenchaetothrips sp. & 103 & 23 \\
2 & Hemiptera & Cicadellidae & Cofana sp. & 97 & 22 \\
3 & Hemiptera & Delphacidae & Nilaparvata lugens & 90 & 117 \\
4 & Hemiptera & Alydidae & Leptocorisa oratorius & 57 & 133 \\
5 & Hemiptera & Cicadellidae & Nephotettix virescens & 40 & 30 \\
6 & Orthoptera & Acrididae & Oxya chinensis & 43 & 75 \\
\hline
\end{tabular}

Table 2. The abundance of carnivores found in manipulated plots $(\mathrm{M}+)$ and non-manipulated plots $(\mathrm{M} 0)$

\begin{tabular}{|c|c|c|c|c|c|}
\hline \multirow{2}{*}{ No } & \multirow{2}{*}{ Order } & \multirow{2}{*}{ Family } & \multirow{2}{*}{ Genus/species } & \multicolumn{2}{|c|}{ Abundance } \\
\hline & & & & Manipulated plot $(\mathrm{M}+)$ & Non Manipulated Plot (M0) \\
\hline 1 & Diptera & Empididae & Drapetis sp. & 145 & 184 \\
\hline 2 & Diptera & Dolichopodidae & Syntormon sp. & 28 & - \\
\hline 3 & Hymenoptera & Eulophidae & Tetrastichus sp. & 92 & 125 \\
\hline 4 & Hymenoptera & Trichogrammatidae & Trichogramma sp. & 49 & 70 \\
\hline 5 & Coleoptera & Coccinellidae & Micraspis vincta & 21 & 31 \\
\hline 6 & Araneae & Araneidae & Araneus sp. & 69 & 40 \\
\hline 7 & Araneae & Tetragnathidae & Tetragnatha sp. & 37 & 39 \\
\hline 8 & Araneae & Linyphiidae & Atypena sp. & 23 & - \\
\hline
\end{tabular}

Table 3. Average herbivorous and carnivorous diversity index in the manipulated $(\mathrm{M}+)$ and the non-manipulated (M0) plots. The index differentiation was determined using t-test with Bonferroni Correction

\begin{tabular}{ccc}
\hline \multirow{2}{*}{ Plot } & \multicolumn{2}{c}{ Diversity Index } \\
\cline { 2 - 3 } & Herbivore & Carnivore \\
\hline $\mathrm{M}+$ & 1.465 & 2.037 \\
$\mathrm{M} 0$ & 1.452 & 1.838 \\
\hline
\end{tabular}

Table 4. Average of the population, diversity index, and number of other arthropod species in the manipulated plot $(\mathrm{M}+)$ and the non-manipulated plot (M0)

\begin{tabular}{cccc}
\hline Treatments & $\begin{array}{c}\text { Mean } \\
\text { population }\end{array}$ & $\begin{array}{c}\text { Diversity } \\
\text { Index }\end{array}$ & $\begin{array}{c}\text { Number of } \\
\text { species }\end{array}$ \\
\hline M+ & 54 & 0.74 & 13 \\
M0 & 66 & 1.04 & 10 \\
\hline
\end{tabular}

Remarks: There were no significant difference between two plots on mean population and diversity index with t-test. 


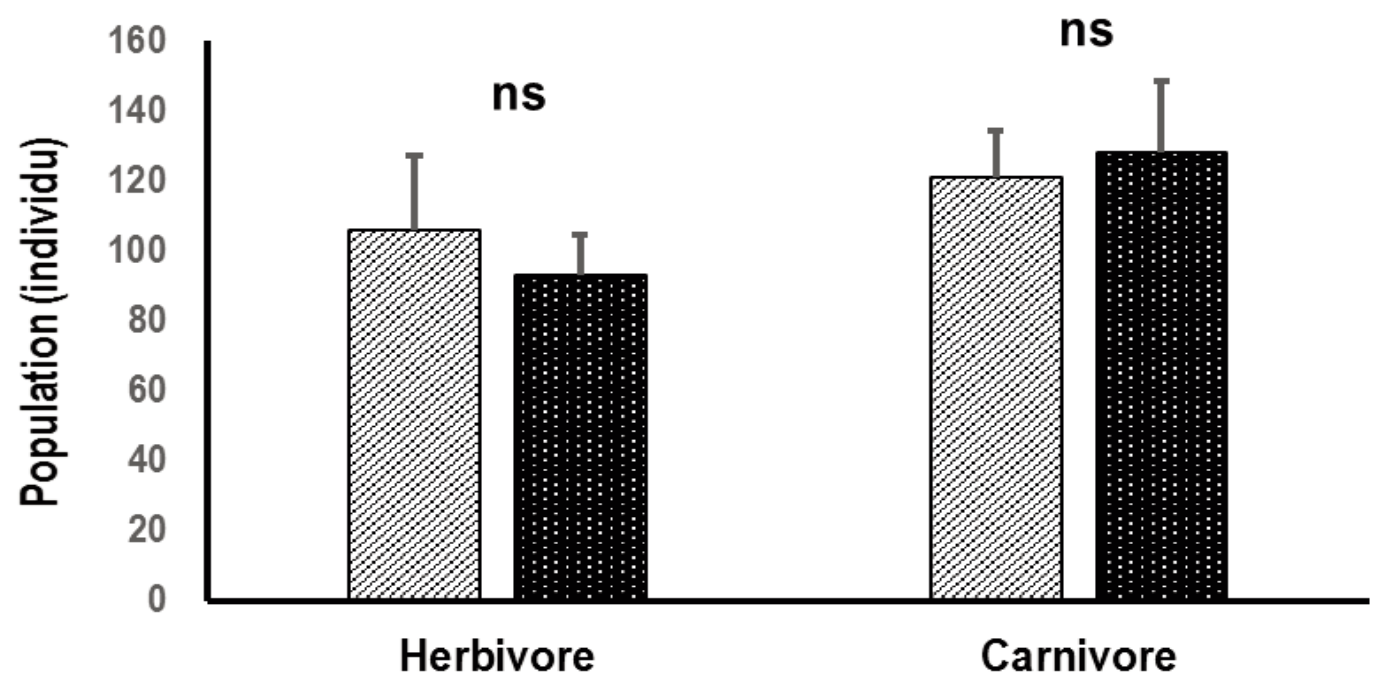

Figure 3. Mean population of herbivores and carnivores found in manipulated plots (gray pattern) and non-manipulated plots (dotted-black). Note: ns showed that the two plots were not significantly differed on t-test with Bonferroni Correction $(\alpha=0.05)$.

Table 5. The establishment of detritivore and/or pollinator on plot with- $(\mathrm{M}+)$ and without manipulation (M0)

\begin{tabular}{clllcc}
\hline No & \multicolumn{1}{c}{ Order } & \multicolumn{1}{c}{ Family } & \multicolumn{1}{c}{ Genus/species } & M+ & M0 \\
\hline 1 & Diptera & Ephydridae & Psilopa sp & + & + \\
2 & Diptera & Ephydridae & Scatella stagnalis & + & + \\
3 & Diptera & Tipulidae & Tipula sp & + & + \\
4 & Diptera & Tephritidae & Cecidochares conexa & + & + \\
5 & Diptera & Ephydridae & Paralimna sp & + & + \\
6 & Diptera & Culicidae & Culicid 1 & + & + \\
7 & Orthoptera & Tetrigidae & Species 1 & + & + \\
8 & Diptera & Chloropidae & Mepagchymerus ensifer & + & - \\
9 & Diptera & Celyphidae & Celyphid 1 & + & - \\
10 & Diptera & Muscidae & Musca domestica & + & - \\
11 & Diptera & Stratiomydae & Hermetia sp & - & + \\
12 & Diptera & Chironomidae & Chironomus sp & - & + \\
13 & Diptera & Ephydridae & Notiphila sp & - & + \\
14 & Hemiptera & Corixidae & Micronecta quadristagata & - & + \\
15 & Coleoptera & Curculionidae & Apion sp & - & + \\
16 & Colembola & Entomobryidae & Entomobryid 1 & - & + \\
\hline
\end{tabular}

Remarks: The attendance of arthropods were marked with + (present) or - (absent).

were not significantly different based on t-test (Table 4). Nonetheless, the identification of arthropods in both plots showed the difference in the number of species (Table 4 and Table 5).

\section{Discussion}

The research proved two things. First, the existence and the abundance of herbivores and carnivorous arthropods were caused by the availability of additional feed for the two groups of arthropods, namely pollen and nectar from flowering plants. Second, the abundance of the carnivores was closely related to the abundance of other arthropods that fall prey.
The abundance and the existence of carnivores seemed to be influenced by the existence of flowering plants, as shown by other studies, for example by Krakos et al. (2011) and Allifiah et al. (2013). A study conducted by Silveira et al. (2009) showed that Marigold (Tagetes erecta) planted between rows of shallots could increase the diversity of predators in the area where it was planted. Meanwhile, Entling and Dobelli (2009) and Saona et al. (2011) in their research showed that carnivorous arthropods, including spiders, were more abundant in plots planted with flowering plants.

Even though this research did not show a significant 
difference between the abundance and diversity of arthropods in both plots, the result presented that the two different herbivores in both plots were different. For instance, Stenchaetothrips sp. and Cofana sp. were more abundant in the manipulated plot. On the other hand, $N$. lugens and $L$. oratorius were more abundant in the non-manipulated plot. $N$. lugens was now becoming a pest in rice fields. Meanwhile, two different carnivores, Larva Syntormon and Atypena sp. were only found in the manipulated plot. Imago and Syntormon sp., which were like Dolichopodidae (order Diptera), were included in predators on small insects (Sato, 1991; Tonguc et al., 2016).

Meanwhile, Atypena sp. was one of predator spiders found in $N$. lugens and N. virescens. There were also Collembola, thrip, small flies, and other insects (Banerji et al., 1993; Sigsgaard et al., 2001a \& b). A study conducted by Banerji et al. (1993) presented that temporary abundance of Atypena sp. was influenced by its prey, especially $N$. lugens. However, the result of this study showed that the existence of Atypena might not only influenced by planthopper and leafhopper, but also by other preys, such as Collembola of Entomobryidae family, which was found in the manipulated plot. The existence of arthropods like Collembola was typically caused by high organic materials, which was found in compost worms (Salmon dan Ponge, 2001). Bilde et al. (2000) clarified that Collembola was the most important prey to polifag predator, including spiders.

The existences of the two predators were believed to quickly control the abundance of herbivores (occurs in the $3^{\text {rd }}$ observation; Figure 1) in the manipulated plot compared with the non-manipulated plot, which decreased in the $4^{\text {th }}$ observation. The impact of predation by the carnivores intensively found in the manipulated plot was also seen from the average of the herbivore abundances, which were lower than those in the non-manipulated plot (Figure 3)

This research showed that the organic matter in the soil improved the diversity and the abundance of soil arthropods which affected the abundance and diversity of carnivorous predators. Furthermore, planting of flowering plants was meant to increase the existence of herbivorous and carnivorous arthropods. In general, organic matter in the soil and flowering plants would increase the diversity of arthropods that could support a mechanism of controlling harmful arthropods in the rice ecosystems naturally and in a balanced way.

\section{CONCLUSIONS}

This research showed that manipulation of habitat on the elements of the growing media (soil) through the addition of organic matter and management of herbivores through the planting of flowering plants to provide feed as well as shelter for natural enemies was potential to create the independent ecosystem for rice cultivation ecosystem. However, a more thorough research was still needed, especially to improve the success of such system in different areas which differed in specific habitat characteristics.

\section{ACKNOWLEDGEMENT}

This research was supported by the Human Resources Agency of Ministry of Agriculture Republic of Indonesia. The researcher specially thanked Ms. Sunari Harto who had allowed the research to be conducted in her land, Niken Rasmi Paramita, S.P., M.Sc. who had helped translating the report, and Meylia Rachmawati, SP for helping the researcher to identify the arthropods.

\section{REFERENCES}

Allifiah, A. N. A. F., W. Yanuwiadi, Z. P. Gama, dan A. S. Leksono. 2013. Refugia Sebagai Mikrohabitat untuk Meningkatkan Peran Musuh Alami di Lahan Pertanian. Prosiding FMIPA Universitas Pattimura: 113-116.

Aryantha, I. P. 2002. Membangun Sistem Pertanian Berkelanjutan. paper presented to Development of Sustainable Agricultural System, One Day Discussion on The Minimization of Fertilizer Usage. Jakarta, 6 May.

Banerji, D. K., P. K. Nanda, P. K. Bera, and S. C. Sen. 1993. Seasonal Abundance of Important Some Spider Groups in Rice Agroecosystem. Records of the Zoological Survey of India, 93: 275-281.

Bilde, T., J. A. Axelsen, and S. Toft. 2000. The Value of Collembola from Agricultural Soils as Food for a Generalist Predator. Journal of Applied Ecology, 37: 672-683.

Chandra, K. 2005. Organic Manure. Banglaore, India: Regional Centre of Organic Farming, pp. 1-46.

Entling, M. H. S. and J. Dobeli. 2009. Sown Wild Flower Areas to Enhance Spiders in Arable Fields. Agriculture Ecosystems and Environment Journal, 133: 19-22.

Frank, T. and I. Kunzle. 2006. Effect of Early Succession in Wildflower Areas on Heteroptera Assemblages (Insecta: Heteroptera). European Journal of Entomology, 103(1): 61-70. 
Hadi, M., R. C. H. Soesilohadi, F. X. Wagiman, dan Y. R. Suhardjono. 2015. Keragaman Arthropoda Tanah pada Ekosistem Sawah Organik dan Sawah Anorganik (Diversity of Soil Arthropods in Organic and Inorganic Paddy Rice Field Ecosystem). Prosiding Seminar Nasional Masyarakat Biodiv Indon. 1(7): 1577-1581.

Hanafiah, K. A. 2010. Rancangan Percobaan: Teori dan Aplikasi. Ed. Ketiga. Jakarta: Rajawali pers, pp. 260.

Herlinda, S., Waluyo, S. P. Estuningsih, dan C. Irsan. 2008. Perbandingan Keanekaragaman Spesies dan Kelimpahan Arthropoda Predator Penghuni Tanah di Sawah Lebak yang Diaplikasi dan Tanpa Aplikasi Insektisida. J. Entomol. Indon., 5(2): 96-107.

Kariada, I. K., dan I. B. Aribawa. 2005. Pengaruh Residu Jenis dan Dosis Pupuk Organik terhadap Pertumbuhan dan Hasil Padi di Subak Rejasa Kabupaten Tabanan Bali. [online] BPTP Bali. Available at: http://ntb.litbang. pertanian.go. id/document.php?folder=ind/2006/TPH\&filename $=$ pengaruhsistem $\&$ ext $=$ doc $[$ Accessed 27 November 2015].

Krakos K., A. M. Booth, J. S. Ardner and M. Eipp. 2011. Nectar for Plant Defense: the Feeding of the On-Active Coccinellid Beetle, Curinus coeruleus, on Extra-Floral Nectaries of Hawaiian Native Hibiscus Brackenridgei. International Journal of Insect Science, 3: 11-21.

Krebs, C. J. and A. J. Kenney. 2011. Program for Ecological Methodology. 2nd ed. Vancouver, Canada: Dept of Zoology University of British Columbia.

Laba, I. W., K. Djatnika, dan M. Arifin. 2000. Analisis Keanekaragaman Hayati Musuh Alami pada Ekosistem Padi Sawah. Prosiding Simposium Keanekaragaman Hayati Arthropoda pada Sistem Produksi Pertanian, PEI-KEHATI: 207-217.

Marpaung, A. E. 2014. Pemanfaatan Pupuk Organik Padat dan Pupuk Organik Cair dengan Pengurangan Pupuk Anorganik terhadap Pertumbuhan Tanaman Jagung (Zea mays L). Jurnal Saintech, $6(4)$.

Muhibah, T. I. dan A. S. Leksono. 2015. Ketertarikan Arthropoda terhadap Blok Refugia (Ageratum conyzoides, Capsicum frutescens, dan Tagetes erecta) dengan Aplikasi Pupuk Organik Cair dan Biopestisida di Perkebunan Apel Desa Poncokusumo. Jurnal Biotropika, 3(3): 123127.

Pimentel, D. and C. A. Edwards. 1982. Pesticides and Ecosystems. Bio Science, 32(7): 595-600.

Pimentel, D., H. Acquay, M. Biltonen, P. Rice, M.
Silva, J. Nelson, V. Lipner, S. Giordano, A. Horowitz, and M. W.D'Amore. 1992. Environmental and Economic Costs of Pesticide Use. Bio Science, 42(10): 750-760.

Salmon, S. and J. F. Ponge. 2001. Earthworm Excreta Attract Soil Springtails: Laboratory Experiments on Heteromurus nitidus (Collembola: Entomobryidae). Soil Biology and Biochemistry, 33: 19591969.

Saona, C. R., B.R. Blaauw, and R. Isaacs. 2011. Manipulation of Natural Enemies in Agroecosystems: Habitat and Semiochemicals for Sustainable Insect Pest Control. In: M. L. Larramendy and S. Soloneski, ed., Integrated Pest Management and Pest Control-Current and Future Tactics, 1st ed. Croatia: InTech, pp. 89-126.

Sato, M. 1991. Comparative Morphology of The Mouthparts of The Family Dolicophodidae (Diptera). New Series, 45: 49-75.

Settle, W. H., H. Ariawan, E. T. Astuti, W. Cahyana, A. H. Hakim, D. Hindayana, and A. S. Lestari. 1996. Managing Tropical Rice Pests Through Conservation of Generalist Natural Enemies and Alternative Prey. Ecology, 77 (7): 19751988.

Sigsgaard, L., S. Toft and S. Villareal. 2001a. Diet Dependent Fecundity of The Spiders Atypena formosana and Pardosa pseudoannulata, Predators in Irrigated Rice. Agricultural and Forest Entomology, 3: 285-295.

Sigsgaard, L., S. Toft and S. Villareal. 2001b. Diet Dependent Survival, Development and Fecundity of The Spider Atypena formosana (Oi) (Araneae: Linyphiidae) - Implication for Biological Control in Rice. Biological Science and Technology, 11: 233-244.

Silveira, L.C.P., E. B. Filho, L. S. R. Pierre, F. S. C. Peres, J. N. C. Louzada. 2009. Marigold (Tageteserecta L.) as an Attractive Crop to Natural Enemies in Onion Fields. Sci. Agric. (Piracicaba, Braz.), 66 (6): 780-787.

Supartha, N. Y., G. Wijana, dan G. M. Adnyana. 2012. Aplikasi Jenis Pupuk Organik pada Tanaman Padi Sistem Pertanian Organik. EJurnal Agroekoteknologi Tropika, 1( 2): 9697.

Tonguc, A., I. Y. Grichanov, and S. Naglis. 2016. Checklist of the Dolicophodidae (Diptera, Brachycera) of Turkey. Turkish Journal of Zoology, 40: 14-26.

Widiarta, I. N., D. Kusdiaman, dan Suprihanto. 2006. Keragaman Arthropoda Pada Padi Sawah Dengan Pengelolaan Tanaman Terpadu. J. HPT Tropika, 6(2): 61-69.

Wilkin, K. M., D. D. Ackerly, and S. Stephens. 2016. 
Climate Change Refugia, Fire Ecology and Management. Forests, 7(4): 77-90. 